\title{
Emphasis on the movement towards sustainable development in the global goal-setting of the Russian Railways Company
}

\author{
Liana Chechenova ${ }^{1, *}$ \\ ${ }^{1}$ 190031, Russia, Saint Petersburg, Emperor Alexander I St Petersburg State Transport University
}

\begin{abstract}
Research background: In recent years, we can observe a global transformation of transport systems in general, and first of all, railway transport. This transformation is predetermined by large-scale social, technological and economic progress in the transport services market, formed by a new consumption model.

Purpose of the article: The purpose of this research is determination of the relationship between the adoption of a sustainable development policy and the effectiveness of the implementation of infrastructure development projects of JSC "Russian Railways".

Methods: The research methodology is based on the analysis of international approaches and evaluation criteria for ESG factors using analytical procedures for identifying cause-and-effect relationships of the Russian railway transport development strategy within the framework of ESG.

Findings \& Value added: The assessment of the strategic priorities of JSC "Russian Railways" in the strategy of sustainable development is given with the justification of trends and development criteria. The format of compliance of the Russian railway transport development strategy with the goals of sustainable growth with a comparison of national projects, state programs and strategic goals for the development of the transport complex of the Russian Federation is established. The analysis confirms the possibility of using the main results of the study when making decisions within the framework of the globalization of sustainable development of infrastructure sectors of the economy and, in particular, transport to attract "green" investments in projects for the development of main infrastructure with priority settings for energy efficiency, environmental friendliness and safety of the railway transport system.
\end{abstract}

Keywords: railway transport; globalization; sustainable development; priorities of Russian railways

JEL Classification: $F 63 ; L 92$

* Corresponding author: liana1981-149@,mail.ru 


\section{Introduction}

The digital transformation of the transport industry is becoming an inevitable process of business globalization and its adaptation to the new realities and preferences of the digital world, since the dynamics of changes in the preferences of the modern consumer and the forms of his consumption of goods and services are the determining factor of digital transformations.

In recent years, we can observe a radical transformation of transport systems in general and, above all, railway transport. This transformation is predetermined by large-scale social, technological and economic progress in the transport services market, formed by a new consumption model. New markets for goods and services are emerging, old ones are being destroyed and modified. Significant changes have affected geodynamics, organization and forms of transportation. The transport system is moving into the format of an eco-friendly (safe), social (highly mobile) and economical system (Wang et al., 2020; Jong and From, 2021; Svatavskaya et al., 2020).

The issues of globalization of sustainable development are of interest both for business communities and for the national economy of states. The concept of sustainable development provides not only "green" guidelines, but also creates an exceptional factor of investment attractiveness. At the same time, the implementation of investment projects is a more conscious and less speculative process, in which not only business is interested, but also the state, as shown in the study (Shaydurova et al., 2018).

It is worth noting the studies (Abdi et al., 2020) of the interdependence and mutual influence of the principles of sustainable growth and the cost of transport companies. The authors conducted a panel analysis of the data of transport companies, the results of which confirm the positive relationship between the assessment of the environmental component (Env) and the assessment of the company's value indicators and financial indicators, respectively. This confirms the increase in the company's market value and the return on invested funds in the case of positive dynamics of ESG (Environmental, Social, and Corporate Governance) indicators.

In addition, there are convincing studies and evidence that the increase in social capital has a positive effect on sustainable business models (Kluza et al., 2021). The limitation and complexity of this issue is to include environmental, social and managerial factors in the analysis, in particular their standardization and classification. In our opinion, the approach and methodology of this study will partially solve this problem.

\section{Methodology}

The new guidelines for the activities of Russian Railways accumulate the processes of searching for and implementing sustainable development projects designed to ensure the transparency of the foundations for the use of "green" financing tools.

The purpose of this study is to determine the relationship between the adoption of the policy of globalization of sustainable development and the effectiveness of the implementation of infrastructure projects of Russian railways. Our task is to prove that the functioning of the Company within the framework of the established principles of sustainable development of ESG contributes to the improvement of its operational activities.

Currently, the main objectives of the Holding are to achieve national goals by expanding the capabilities of the transport infrastructure and increasing the economic connectivity of the territories. Considering the strategic nature of the development of railway transport, we have structured the key areas of transport services, taking into account their positive impact on the business processes implemented in the industry (Fig. 1). 


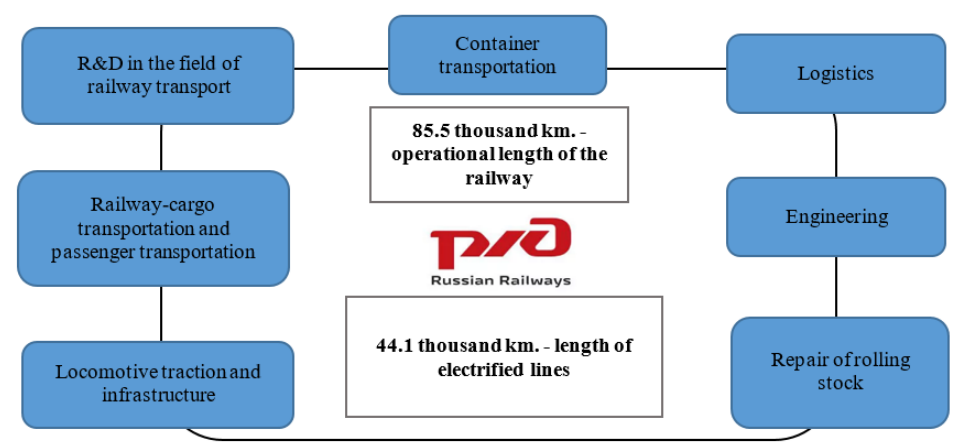

Figure 1. The scope of activity of JSC "Russian Railways" for the provision of transport services Source: author (2021)

It is necessary to note the preliminary trend of Russian railways in compliance with the principles of environmental protection and compliance with safety measures, which is enshrined in the Environmental Strategy of the Holding until 2020 and for the future until 2030 (The environmental strategy of JSC, 2021). Currently, the company's share in atmospheric emissions, wastewater pollution and the creation of waste substances is no more than $1 \%$ compared to all organizations operating on the territory of the Russian Federation. At the same time, in 2019 in accordance with the corporate Program of measures to increase environmental responsibility, there is a reduction in atmospheric emissions, wastewater discharges and water consumption in the range of 3-4\% compared to the previous period.

In order to reduce the negative impact of railway transport on the environment, the Holding actively uses "green" technologies for the electrification of track lines intended for passenger transportation. The economic effect of the implementation of energy-efficient projects amounted to more than 2 billion rubles in 2019, which indicates the leading positions held by JSC "Russian Railways" among international freight and passenger rail carriers in terms of energy and environmental efficiency.

\section{Results}

\subsection{The strategic priorities of the Russian railways are determined in accordance with the principles of sustainable development (Fig. 2):}

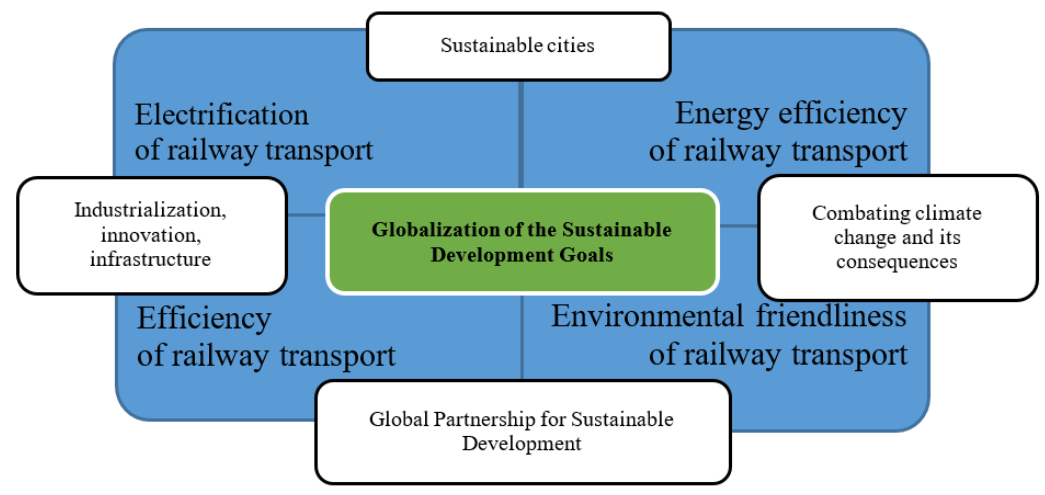

Figure 2. Strategic priorities of Russian railways in the field of sustainable development

Source: author (2021) 
The main event of the Strategy for the Development of Railway Transport in the Russian Federation until 2030 is the electrification of the railway transport system. Accordingly, the Holding's task is to support environmentally oriented projects for the construction and reconstruction of infrastructure facilities, as well as environmentally oriented rail transportation, which can include electric trains and electric locomotives to reduce harmful emissions and minimize energy consumption. Assessing rail transport as the most energyefficient mode of transport compared to others, it should be noted the expansion of the urban and high-speed infrastructure geography over the past 10 years and the minimum $3 \%$ energy consumption of the railway sector, which accounts for about $9 \%$ of global passenger traffic and $7 \%$ of cargo traffic.

\section{PASSENGER TRANSPORT}

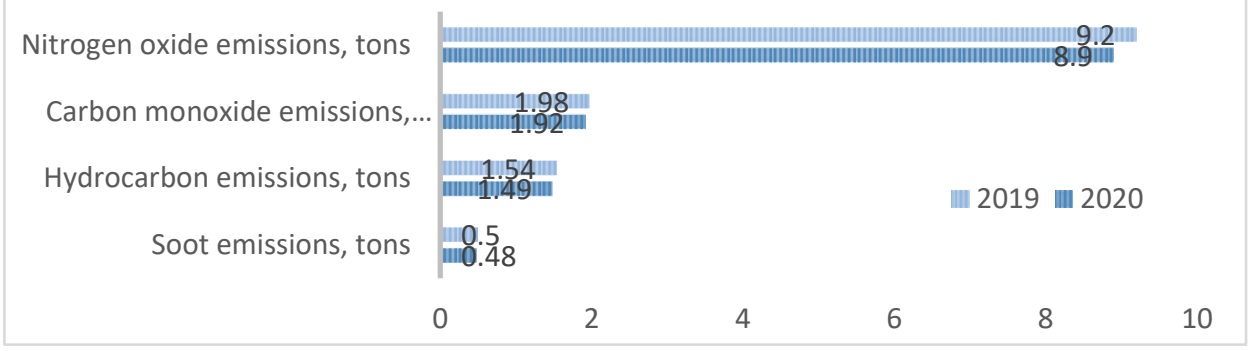

Figure 3. Emissions from passenger rail transport

Source: author (2021)

In order to develop the system of accounting and management of greenhouse gas emissions, a program of organizational and technical measures aimed at reducing greenhouse gas emissions in JSC "Russian Railways" for 2020-2025 was approved. The implementation of measures under this program makes it possible to further reduce direct and indirect emissions of harmful atmospheric substances, which can be reduced by increasing the share of renewable energy supplied to the network through which electricity is supplied to power locomotives.

\section{CARGO TRANSPORT}

Nitrogen oxide emissions, tons

Carbon monoxide emissions, tons

Hydrocarbon emissions, tons

Soot emissions, tons

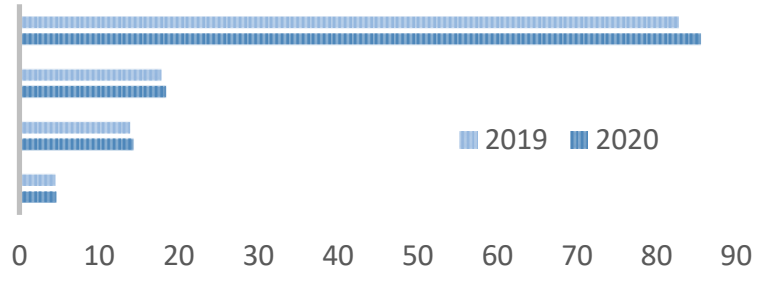

Figure 4. Emissions from cargo rail transport

Source: author (2021) 
Taking into account the low energy intensity and intensity of carbon dioxide emissions in railway transport, the development of railway transport is an important element of improving energy security and reducing emissions of harmful substances into the atmosphere. Shifting the volume of passenger and freight traffic from more intensive modes of transport (such as personal cars, trucks and airplanes) to rail transport will significantly reduce the amount of such emissions and reduce the negative impact on the environment. Due to the fact that the Company's activities are associated with the constant expansion of the capacity of passenger public transport, the construction and modernization of passenger infrastructure, and an increase in the share of transportation using environmentally friendly electric transport, JSC "Russian Railways" makes an important contribution to the decarbonization of the economy (Zhuravleva, 2018; Zhuravleva et al., 2019). This is the basis for the Company's issuance of green bonds and provides investors with the opportunity to support the financing of low-carbon transport assets and infrastructure in the Russian Federation.

\subsection{The attraction of green financing instruments by Russian railways for the implementation of environmental infrastructure projects is justified}

The issue of green bonds provides a guaranteed attraction of capital investments and investments for environmentally friendly projects, both current and prospective. The principles of green bonds (GBP) imply transparency and disclosure of information, promote integrity in the development of the green bond market by clarifying the approach to issuing green bonds. GBP is intended for wide use by the market: they provide issuers with recommendations on the key components involved in the launch of a reliable green bond; they help investors by making available the information necessary to assess the impact of investments in environmental resources, their investments in green bonds; and they help underwriters by moving the market to standard disclosure, which greatly facilitates the process of implementing the transaction. One of the participants in the green bond market is the Russian Railways (Table 1).

Table 1. Economic effect of the project implementation

\begin{tabular}{|c|c|c|}
\hline \multicolumn{3}{|c|}{ Bond code } \\
\hline XS1843437036 & CH0522690715 & RU000A102564 \\
\hline \multicolumn{3}{|c|}{ Maturity date } \\
\hline 23 May 2027 (8 years) & 12 March 2026 (6 years) & $\begin{array}{l}\text { Without a fixed repayment } \\
\text { period }\end{array}$ \\
\hline \multicolumn{3}{|c|}{ Issue size } \\
\hline 500000000 euro & 250000000 Swiss francs & 100000000000 rubles \\
\hline \multicolumn{3}{|c|}{ Coupon } \\
\hline $2,2 \%$ fixed, annual & $0,84 \%$ fixed, annual & $7,25 \%$ floating, every 182 days \\
\hline
\end{tabular}

Source: author (2021)

\subsection{The priorities of Russian railways in the strategy of sustainable development are systematized}

The analysis of the current state of the railway industry in the context of the ESG principles allowed us to identify the main priorities of JSC "Russian Railways" in the field of sustainable development, based on the strategic objectives of the Holding and projects that reduce the negative impact on the environment (Fig. 5). 


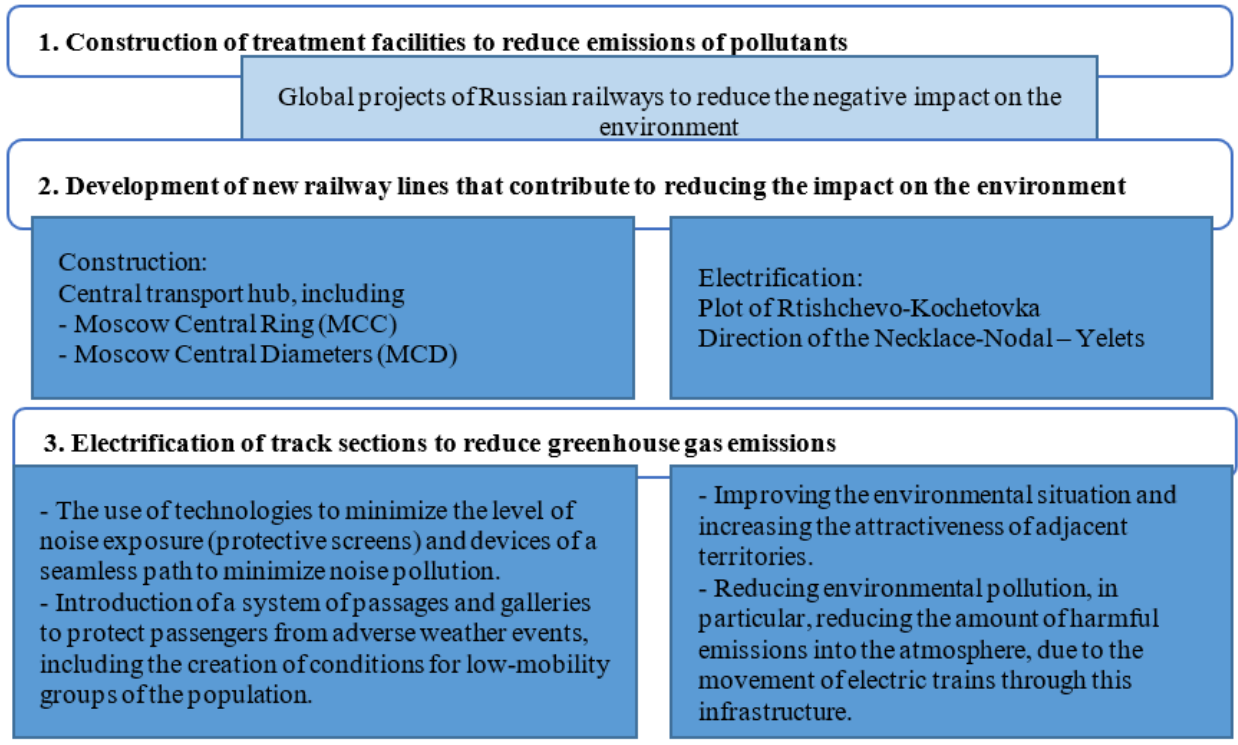

Figure 5. The economic effect of the project implementation

Source: author (2021)

Assessing the impact of the" green "projects of JSC" Russian Railways " on the economic growth of the industry as a whole, it is necessary to be guided by the ratio of costs and expected results based on the results of the implementation of projects consistent with the basic principles of sustainable growth, which determines the subject of our future research.

\section{Discussion}

New guidelines for the globalization of economic growth through the implementation of infrastructure projects with a focus on" green "development appeared in 2007 after the global crisis, when the "green" sectors of the economy of the G20 countries took about $16 \%$ of anticrisis spending. This situation can be considered as the primary "pilot" of the concept of a New Green Course. At that time, Russia did not consider it possible to switch to a diversified economic course of development. At present, this transition is not only possible, taking into account the relatively favorable economic situation, but also necessary, since the omission of the possibility of avoiding dependence on raw materials can have irreversible consequences for the national economy of the Russian Federation. The sustainable development of the global economy requires not only financial infrastructure expansion, but also the implementation of social projects with environmental benefits.

The main discussion on the goals and essence of sustainable growth, shown by Eileen de Jong, Marjanneke J. Vijge (2021) confirms that the problem of sustainable development is of great importance for global and national economies and coordinated actions between them. At the same time, the importance of the SDGs is emphasized in the formation of relations: developed and developing economies, towards partnership and management of agreed SDGs in the interests of global growth (De Jong and Vijge, 2021).

The analysis of the impact of the process of economic globalization on the environment, economic growth and the quality of business for the period from 1980 to 2018 identified the positive and negative consequences of economic globalization within the framework of sustainable development. It should be noted that the authors presented new empirical data 
and recommendations on the policy of achieving the Sustainable Development Goals (Wu et al., 2021).

The methodology for assessing the long - term and short-term relationship between globalization and economic growth is presented in Kihombo et al. (2021). The authors took as a basis the use of a three-component indicator of globalization, namely economic, social and political globalization. The results showed that in the short term, economic and social globalization has a positive impact on economic growth, while political globalization has a negative impact on the economic growth of the EU countries. In the long term, economic globalization has a statistically significant positive impact on the economic growth of the EU countries, while social and political globalization has a negative impact on the economic factor.

In recent years, many empirical studies have studied the impact of globalization on the ecological footprint. Most of these studies were based on the globalization index and studied the impact of general globalization and the disaggregated consequences of economic, social and political globalization on the environmental component. However, less attention is paid to financial globalization, which can also affect environmental protection. The authors Acosta et al. (2020) investigate the relationship between financial globalization (FG), economic growth (GDP) and the effectiveness of population density management (PD) in certain countries of Western Asia and the Middle East (WAME) from 1990 to 2017. The results show that financial globalization is an important factor for promoting environmental sustainability in the sample countries, since it reduces the level of pollution. Population density exacerbates the ecological footprint and exacerbates environmental degradation in the sample countries. The study revealed the Environmental Kuznets Curve (EKC) between environmental impacts and economic growth in the context of financial globalization and population density. Based on these results, the economies of States can achieve environmental sustainability and sustainable development by increasing the level of financial globalization.

The methodology for measuring the effectiveness of activities to achieve the Sustainable Development Goals related to the transition to "green" growth is presented in the work of Acosta et al. The article discusses the results of achieving the Sustainable Development Goals (SDGs) in the field of natural capital protection by dividing the concept of "green" growth into four main components (i.e., environmental quality, reduction of greenhouse gas (GHG) emissions, protection of ecosystems and biodiversity, as well as cultural and social value). The work fills an important research gap, since the comparative analysis of sustainability targets contains a clear formulation of indicators for the protection of natural capital, taking into account global green growth indices (Acosta et al., 2020).

To assess the effectiveness of sustainable development in the transformation of the level of globalization in order to achieve a certain level of socio-economic development, scientists Rey et al. (2021) presented an algorithm for analyzing data coverage and calculating target indicators. The results showed the possibilities of the globalization process in the interests of socio-economic development along with scientific and technological progress and the implementation of infrastructure projects, which fully corresponds to the logic of our study.

The issues of supporting the stable position and development of business in the market during the globalization of economic processes at both the macro and micro levels are studied in Pirogova et al. (2020). Despite the strengthening of ties and interaction of economies, which significantly stimulates the development of the transport industry, it is necessary to take into account the negative impact on the environment, the reduction of social responsibility of business, which are the main components of sustainable development. The authors present a system of balanced indicators of sustainable development within the framework of the globalization of economic processes, which is undoubtedly of interest for further research. 


\section{Conclusion}

The conducted research confirms that Russia and the transport sector in particular have achieved insignificant results in solving global environmental problems. The stereotypes of the global development of Russian railways have shifted in favor of environmental friendliness, energy efficiency and transportation safety. This will definitely lead to the transformation of the industry, the emergence of new business models and a revision of the cost structure of transport services, since sustainable development projects generate their ideas as financially attractive and socially significant. In fact, any infrastructure projects can be considered sustainable if they comply with the principles of sustainable development. In a narrower sense, any initiatives that meet certain environmental requirements can be "green". In the world practice, there are facts when infrastructure facilities were created using public private partnership mechanisms and were subsequently certified according to "green" standards.

\section{References}

1. Abdi, Y., Li, X., \& Càmara-Turull, X. (2020). Impact of Sustainability on Firm Value and Financial Performance in the Air Transport Industry. Sustainability, 12(23), 1-23.

2. Acosta, L. A., Maharjan, P., Peyriere, H. M., \& Mamiit, R. J. (2020). Natural capital protection indicators: Measuring performance in achieving the Sustainable Development Goals for green growth transition. Environmental and Sustainability Indicators. 8, Article 100069.

3. De Jong, E., \& Vijge, M. J. (2021). From Millennium to Sustainable Development Goals: Evolving discourses and their reflection in policy coherence for development. Earth System Governance, 7, Article 100087.

4. Jong, E., \& Vijge, M. (2021). From Millennium to Sustainable Development Goals: Evolving discourses and their reflection in policy coherence for development. Earth System Governance, 7, Article 100087.

5. Kihombo, S., Vaseer, A. I., Ahmed, Z., Chen, S. S., Kirikkaleli, D., \& Adebayo, T. S. (2021). Is there a tradeoff between financial globalization, economic growth, and environmental sustainability? An advanced panel analysis. Environmental science and pollution research, Article 34396480.

6. Kluza, K., Ziolo, M., \& Spozc, A. (2021). Innovation and environmental, social, and governance factors influencing sustainable business models - Meta-analysis. Journal of Cleaner Production, 303, Article 127015.

7. Roy, A., Basu, A., \& Dong, X. H. Achieving Socioeconomic Development Fuelled by Globalization: An Analysis of 146 Countries. Sustainability, 13(9), Article 4913.

8. Pirogova, T. E., Poluleh, M. V., Golysheva, N. I., Sorokina, V. V., \& Martyinenko, N. N. Balanced scorecard: essence and importance for making good business decisions to ensure sustainable development of business. Bulletin of the National Academy of Sciences of Republic of Kazahstan, 3(385), 169-177.

9. Shaydurova, A., Panova, S., Fedosova, R., \& Zlotnikova, G. (2018). Investment Attractiveness of "Green" Financial Instruments. Journal of Reviews on Global Economics, 7, 710-715.

10. Svatovskaya, L., Drobyshev, I., Mikhailova, K., \& Khamenok, N. (2020). Criteria of green geoecoprotective technologies in transport construction. Lecture Notes in Civil Engineering, 50, 431-440. 
11. The environmental strategy of JSC "Russian Railways" for the period up to 2020 and the $\begin{array}{lllll}\text { prospect up } & 2030 \text { (2016, June }\end{array}$ https://company.rzd.ru/ru/9353/page/105104?id=958

12. Wang, X., Wong, Y. D., Yuen, K. F., \& Li, K. X. (2020). Environmental governance of transportation infrastructure under Belt and Road Initiative: A unified framework. Transportation Research Part A: Policy and Practice, 139, 189-199.

13. Wu, X. M., Majeed, A., Vasbieva, D. G., Yameogo, C. E. W., \& Hussain, N. (2021). Natural resources abundance, economic globalization, and carbon emissions: Advancing sustainable development agenda. Sustainable development, 29(5), 1037-1048.

14. Zhuravleva, N. A. (2018) Metodologiya issledovaniya cifrovoj transformacii v usloviyah destabilizacii biznes-modelej transportnyh organizacij In: Babkin A. V, (Ed.) Metodologiya razvitiya ekonomiki, promyshlennosti i sfery uslug v usloviyah cifrovizacii (pp. 10-47). SPbPU.

15. Zhuravleva, N., Guliy, I., \& Polyanichko, M. (2019). Mathematical description and modelling of transportation of cargoes on the base digital railway. Environment. Technology. Resources: Proceedings of the 12th International Scientific and Practical Conference. T. II. (pp. 175). Rezekne. 